\title{
ОЦІНЮВАННЯ САНІТАРНОГО СТАНУ СОСНОВИХ НАСАДЖЕНЬ ЗОНИ БЕЗУМОВНОГО ВІДСЕЛЕННЯ У СВІЖИХ БОРАХ ЛІСІВ УКРАЇНСЬКОГО ПОЛІССЯ
}

\begin{abstract}
Оцінено санітарний стан соснових насаджень у свіжих борах лісів Українського Полісся. У соснових насадженнях усіх вікових груп, де припинено лісогосподарську діяльність, питома вага здорових насаджень $\epsilon$ нижчою, ніж у насадженнях поза зоною забруднення. На інтенсивно забруднених територіях основну частку становлять насадження II - IV категорії. Отримані результати підтверджуються результатами однофакторного дисперсійного аналізу, що свідчать: між розподілом дерев за категоріями санітарного стану на пробних площах ППП № 5/5К та ППП № 6/6К існує достовірна різниця: $F_{\text {qакт. }}=$ $11,2>F_{(1 ; 199 ; 0,95)}=3,9$ та $F_{\text {факm. }}=12,6>F_{(1 ; 199 ; 0,95)}=3,9$ відповідно. Було виявлено, що на ППП № 4/4К між досліджуваними показниками така різниця відсутня $-F_{\text {факт. }}=3,0<F_{(1 ; 199 ; 0,95)}=3,9$. Простежено погіршення індексу санітарного стану радіоактивно забруднених насаджень 2,40-2,57 проти 1,89-2,13 у контрольних деревостанах. Розподіл дерев за ступенем панування та життєвості (клас Крафта) демонструє, що найбільша частка деревостану припадає на I та II класи. Встановлено, що на контрольних пробних площах значно краща частка розподілу деревостанів за категоріями товарності деревини (I42-48 \%, II - 35-43\%, III - 12-20\%), ніж на радіоактивно забруднених територіях (I - 28-38 \%, II - 42-44 \%, III - 20-30 \%). Відзначено, що соснові насадження, де своєчасно та належно проводили лісогосподарські заходи, виявилися більш структурно стійкими.
\end{abstract}

Ключові слова: радіоактивне забруднення; лісогосподарська діяльність; індекс санітарного стану; клас Крафта; категорії товарності деревини.

Вступ. Соснова звичайна (Pinus sylvestris L.) $є$ найбільш поширеною породою у лісах, що зазнали значного радіоактивного забруднення та належить до досить пластичних за екологічними вимогами деревних порід (Krasnov et al., 1993; Kozubov et al., 1990; Tikhomirov, Shcheglov \& Sidorov, 1994). Дослідники відзначали, що хвойні деревні породи у 5-10 разів чутливіші до радіаційного опромінення, ніж листяні (Krivolutckii et al., 1988; Pasternak et al., 1990; Savitckii, 1992), та акумулюють радіонукліди у 2-3 рази більше (Maradudin, 1991; Shcheglova \& Tcvetnova, 2001), порівняно з ними. Саме тому соснові насадження можна використовувати як індикатор забруднення екосистеми радіонуклідами у процесі оцінювання та прогнозування санітарного стану лісових масивів на радіоактивно забруднених територіях.

Дослідники встановили (Krasnov, 1998; Stepin \& Biriukov, 1993; Mozolovskaia, 1991), що вже через 10 років після аварії спостерігали збільшення частки деревостанів із порушенням їх стійкості, погіршенням санітарного стану, гальмуванням росту та зменшенням продуктивності радіоактивно забруднених насаджень. Вчені наголошували, що ризик подальшого зниження санітарного стану насаджень внаслідок припинення лісогосподарської діяльності з часом зростатиме. Ефективний захист і охорона деревостанів безпосередньо пов'язані 3 виконанням своєчасних та кваліфікованих лісогосподарських заходів, що стають запорукою належного санітарного стану та підвищують їхню продуктивність.
За результатами досліджень (Buzun, Irkliienko \& Turchak, 2000) встановлено, що в радіоактивно забруднених насадженнях пришвидшуються процеси самозрідження і накопичення відпаду, несвоєчасна утилізація яких призводить до погіршення продуктивності та товарності деревини. У публікаціях (Buntova \& Kuchma, 2011; Kuchma et al., 1996) головною причиною зниження стійкості лісів на забруднених територіях називають шкідники та хвороби, для яких після припинення лісогосподарських заходів створилися сприятливі умови для поширення. Окрім цього, стійкість насаджень значно зменшують несприятливі кліматичні чинники - сніголоми, вітровали, посухи тощо. В інших роботах (Kuchma et al., 1996, 1997; Pliuta \& Didukh, 1996) зазначено, що внаслідок збільшення густоти соснових насаджень у 1,5-2,0 рази створюється додаткова пожежна небезпека внаслідок накопичення відмерлої хвої, дрібних гілок, кори, які повільно розкладаються, але дуже добре горять. Дослідники (Krasnov, Buzun \& Prystupa, 1998; Stepanchik, Usanova \& Savluk, 1997) встановили, що припинення лісогосподарської діяльності в соснових насадженнях призвело до збільшення кількість дерев 4-6 категорій стану; зменшення кількості дерев 13 категорії; відбулося збільшення захаращеності насаджень, доріг і просік; посилилися процеси накопичення сухостою, валіжу, всихання і відпаду дерев, що спостерігали як на жердняковій стадії розвитку, так і у старшому віці. Загалом відзначено значне погіршення сані-

\section{Інформація про авторів:}

Мельник Вікторія Вікторівна, здобувач, кафедра екологіï. Email: melnyk_vika91@ukr.net; https://orcid.org/0000-0002-3551-5085

Цитування за ДСТУ: Мельник В. В. Оцінювання санітарного стану соснових насаджень зони безумовного відселення у свіжих борах лісів Українського Полісся. Науковий вісник НЛтУ України. 2019, т. 29, № 3. С. 39-43.

Citation APA: Melnyk, V. V. (2019). Assessment of the sanitary condition of the scotch pine plantatuons in fresh pine forests of Ukrainian Polissia exclusion zone. Scientific Bulletin of UNFU, 29(3), 39-43. https://doi.org/10.15421/40290308 
тарного стану насаджень.

Аналіз літературних матеріалів свідчить, що, незважаючи на важливість вивчення змін санітарного стану насаджень, виключених із господарського обігу внаслідок радіаційного забруднення, їм не було приділено відповідної уваги. Окремі проблеми вивчено фрагментарно, деякі питання залишилися поза увагою дослідників та потребують поглибленішого вивчення. Саме тому здійснення цих досліджень є досить актуальним, адже це дасть змогу отримати наукові результати для стабілізації та покращення ситуації в лісах та обгрунтувати доцільність заходів щодо реабілітації забруднених лісів.

Об'скти та методика дослідження. Для оцінки санітарного стану соснових насаджень закладали пробні площі у свіжих борах Народицького лісництва ДП "Народицьке спеціалізоване лісове господарство", де було повністю припинено лісогосподарську діяльність внас- лідок високих рівнів радіоактивного забруднення грунту, та в Малинському лісництві ДП "Малинське лісове господарство", де своєчасно вживали лісогосподарські заходи по догляду за лісом (контроль). Докладну характеристику пробних площ навели у табл. 1. Пробні площі закладали згідно з загальноприйнятими в лісівництві та екології методиками. В основу досліджень поклали класичний метод порівняльної екології лісу з його деталізацією за окремими еколого-лісівничими напрямами.

На пробних площах проводили суцільний переоблік деревостанів, визначали таксаційні показники насаджень. Оцінювання бонітету насаджень здійснювали за допомогою шкали М. М. Орлова. Проводили додатковий опис насаджень за розподілом дерев однієї популяції, за ступенем панування і життєвості та оцінювали за класом товарності деревини, за категоріями технічної придатності.

Табл. 1. Характеристика постійних пробних площ

\begin{tabular}{|c|c|c|c|c|c|c|}
\hline \multirow{2}{*}{ Показник } & \multicolumn{6}{|c|}{ Таксаційний показник лісових насаджень на ППП } \\
\hline & № 4 & № 4K & № 5 & № 5K & № 6 & № $6 \mathrm{~K}$ \\
\hline Квартал/виділ & $40 / 8$ & $54 / 11$ & $40 / 10$ & $59 / 12$ & $58 / 6$ & $60 / 8$ \\
\hline Щільність радіоактивного забруднення грунту, кБк/м² & $267^{ \pm 12}$ & $7,5^{ \pm 0,4}$ & $245^{ \pm 14}$ & $5,6^{ \pm 0,3}$ & $259^{ \pm 16}$ & $5,7^{ \pm 0,7}$ \\
\hline ТУМ & \multicolumn{6}{|c|}{ свіжий бір $\left(\mathrm{A}_{2}\right)$} \\
\hline Вік, років & 60 & 55 & 75 & 70 & 100 & 95 \\
\hline Склад насаджень & \multicolumn{6}{|c|}{$10 \mathrm{C}_{3}$} \\
\hline Середня висота, м & 16 & 24 & 22 & 26 & 24 & 27 \\
\hline Середній діаметр, см & 20 & 28 & 28 & 32 & 30 & 30 \\
\hline Клас бонітету & 2 & 2 & 1 & 1 & 1 & 1 \\
\hline Підріст & \multirow{2}{*}{\multicolumn{6}{|c|}{$\begin{array}{c}\text { відсутній } \\
\text { поодинокий }\end{array}$}} \\
\hline Підлісок & & & & & \multicolumn{2}{|c|}{ поодинокий } \\
\hline Проективне покриття трав'яно-чагарникового ярусу, \% & $50-55$ & $45-50$ & $55-60$ & $75-80$ & $50-55$ & $75-80$ \\
\hline Проективне покриття мохового ярусу, \% & $85-90$ & $75-80$ & $85-90$ & $85-90$ & $80-85$ & $85-90$ \\
\hline Грунт & \multicolumn{6}{|c|}{ дерново-середньопідзолистий піщаний } \\
\hline Асоціація & \multicolumn{6}{|c|}{ сосновий ліс зеленомоховий } \\
\hline
\end{tabular}

Основною метою досліджень є сучасне оцінювання санітарного стану насаджень у зоні безумовного відселення на територіях лісового фонду, де припинено лісогосподарську діяльність. За методикою Українського науково-дослідного інституту лісового господарства i агролісомеліорації ім. Г. М. Висоцького за 6-бальною шкалою визначали санітарний стан кожного дерева 3 подальшим обчисленням середнього індексу санітарного стану насадження, який обраховували за формулою (1). Індекси стану насаджень характеризуються: 1,0 1,50 - здорові; 1,51-2,50 - послаблені; 2,51-3,50 - дуже послаблені; 3,51-4,50 - всихаючі; 4,51-6,00 - сухостійні.

$$
I=\sum_{i=1}^{6} i \cdot n_{i} / \sum_{i=1}^{6} n_{i}
$$

де: $n_{1}, n_{2}, \ldots, n_{6}-$ кількість дерев відповідної категорії санітарного стану. Статистичну обробку отриманих даних проводили за загальноприйнятими методами за допомогою прикладного пакету програм Microsoft Excel.

Результати досліджень та їх обговорення. Зниження життєздатності соснових деревостанів у зоні безумовного відселення значною мірою характеризується розподілом дерев за категоріями санітарного стану. У Народицькому лісництві, де рівень радіоактивного забруднення грунту не давав змоги вживати будь-які лісогосподарські заходи, діапазон варіювання питомої ваги окремих категорій дерев значно коливався. Здорові дерева сосни (І категорія) становили від 29 до $33 \%$, ослаблені сосни (II категорія) - 29-33 \%, дуже ослаблені (III категорія) - 13-17\%, всихаючі і всохлі (IV-VI категорії) - 22-24\% від загальної кількості дерев. В Малинському лісництві, де рівень радіоактивного забруд- нення є низьким та своєчасно виконували повноцінні лісогосподарські роботи, санітарний стан дерев значно кращий: I категорія - 47-53 \%, II - 29-37 \%, III - 612 \%, IV-VI - 9-12 \% від загальної кількості дерев. Розподіл дерев за категоріями стану на досліджуваних територіях представлено на рис. 1, що наочно відображає вплив вживання лісогосподарських заходів щодо формування насаджень та його відсутності.

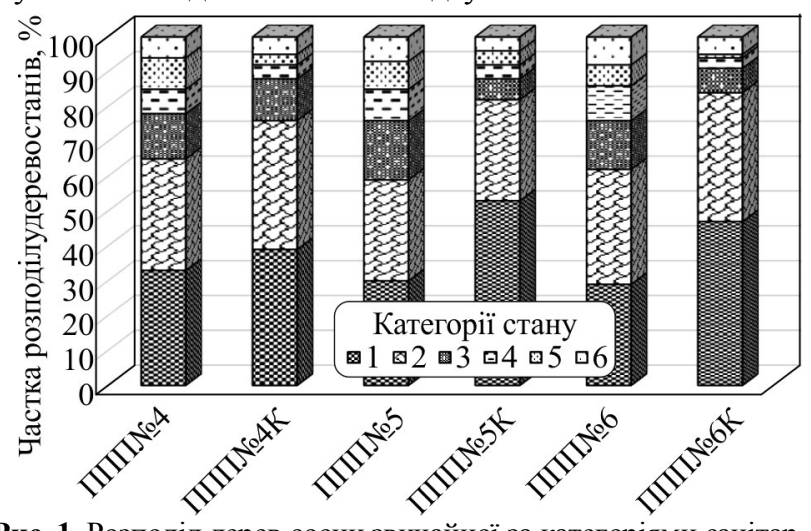

Рис. 1. Розподіл дерев сосни звичайної за категоріями санітарного стану в умовах свіжого бору

Під час аналізу розподілу дерев за категоріями стану в середньовікових соснових насадженнях відзначено, що на ППП № 4 к кількість соснових деревостанів без ознак ослаблення (І категорія) у 1,2 раза більша, ніж на ППП № 4, а ослаблених (категорія II) - у 1,1 раза відповідно. Стосовно розподілу деревостанів за III категорією, істотної різниці не відзначено, проте на ППП № 4 частка дуже ослаблених дерев становить $13 \%$, а на 
ППП № 4К - $12 \%$. Порівнюючи частковий розподіл наступних категорій санітарного стану, можна відзначити, що відмираючих насаджень IV категорії на ППП № 4 у 1,7 раза більше, ніж на контролі (ППП № 4К), свіжого сухостою (V категорія) - більше у 3 рази, а старого сухостою (VI категорія) - у 1,2 раза. Отже, за отриманими результатами можна стверджувати, що у 60річних лісових насадженнях Народицького лісництва значно гірший розподіл деревостанів за категоріями стану, ніж у Малинському лісництві. Хоча, проводячи однофакторний дисперсійний аналіз розподілу дерев за категоріями санітарного стану, не було виявлено істотної різниці середніх значень $-F_{\text {факт. }}=3,0<F_{(1 ; 199 ; 0,95)}=3,9$.

Розподіл соснових деревостанів за категоріями стану було проведено також і для пристигаючих насаджень свіжого бору Українського Полісся. Внаслідок було встановлено, що на ППП № 5 у 1,8 раза менше соснових деревостанів без ознак ослаблення, ніж на ППП № 5К. Проте загальна частка ослаблених деревостанів II категорії був однаковим і становив 29 \%. Аналізуючи подальший розподіл деревостанів, було відзначено значно вищі показники погіршення стану насаджень у Народицькому лісництві, порівняно з контролем. Так, на ППП № 5 кількість дуже ослаблених деревостанів (III категорія) у 2,8 раза більша, ніж на ППП № 5К. Відносно розподілу за іншими категоріями, спостерігаємо подібну різницю і перевищення кількості дерев на ППП № 5, порівняно з ППП № 5К, становлять: для IV категоpiï - 2,2 раза, V категорії - 2,0 рази та старого сухостою (VI категорія) - 1,7 раза. Під час проведення однофакторного дисперсійного аналізу розподілу категорій санітарного стану пристигаючих насаджень було встановлено існування достовірної різниці середніх величин на 95-\%-ому довірчому рівні: $F_{\text {qакт. }}=11,2>F_{(1 ; 199 ; 0,95)}=3,9$.

Аналізуючи розподіл у стиглих соснових деревостанах за досліджуваним показником, було встановлено, що на ППП № 6К здорових насаджень (I категорія) у 1,6 раза більше, ніж на ППП № 6, а ослаблених (II категорія) - у 1,1 раза відповідно. Під час порівняльного аналізу наступних категорій встановлено, що частка дуже ослаблених деревостанів на ППП № 6 становить 14 \%, що у 2 рази більше, ніж на ППП № 6К. Досліджуючи розподіл від IV до VI категорії, можна відзначити різні коливання досліджуваного показника. Так, на ППП № 6К розподіл дерев за категоріями характеризувався такими величинами: для IV $-3 \%, \mathrm{~V}-1 \%$ та VI $5 \%$; тоді як на ППП № 6 ці показники більші - відповідно у 3,3, 6,0 та 1,6 раза. Отримані результати різниці категорій стану стиглих соснових насаджень підтверджуються результатами однофакторного дисперсійного аналізу: $F_{\text {факт. }}=12,6>F_{(1 ; 199 ; 0,95)}=3,9$.

Загальний розподіл досліджуваних деревостанів демонструє, що в забруднених радіонуклідами насадженнях усіх вікових груп питома вага здорових сосен нижча, а ослаблених і дуже ослаблених - набагато вища, ніж у насадженнях поза зоною радіаційного забруднення. Цю тенденцію чітко фіксують індексом санітарного стану дерев (рис. 2). Так, у соснових насадженнях 60 річного віку в Народицькому лісництві індекс стану становить 2,45 , у пристигаючих - 2,57 та стиглих - 2,55. У насадженнях Малинського лісництва, де господарську діяльність проводили своєчасно, індекс стану змінювався від 1,89 до 2,13. Достовірність різниці між значення- ми індексів санітарного стану на пробних площах статистично підтверджено.

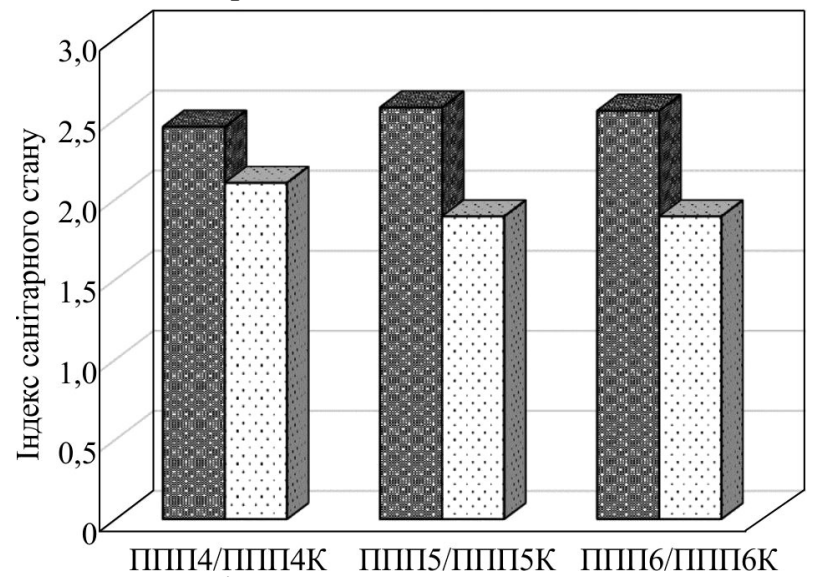

Рис. 2. Індекс санітарного стану соснових насаджень на пробних площах свіжого бору

Ми проаналізували розподіл деревостанів за класом Крафта (табл. 2). Під час порівняльного розподілу дерев за досліджуваним показником відзначено, що на ППП № 4 та ППП № 4К основна маса деревостанів належить до II класу. Частка розподілу дерев за I та III класом на ППП № 4 у 3,3 та 2,2 раза менша, ніж для II класу; на ППП № 4К - у 4,6 та 2,6 раза відповідно. Обсяг дерев IV та V категорії знаходиться у межах від 7 до $12 \%$.

Табл. 2. Розподіл дерев за класом Крафта соснових насаджень

\begin{tabular}{|c|c|c|c|c|c|}
\hline \multirow{2}{*}{ № ППП } & \multicolumn{5}{|c|}{ Розподіл дерев за класом Крафта, \% } \\
\cline { 2 - 6 } & $\mathrm{I}$ & II & III & IV & V \\
\hline ППП № 4 & 16 & 53 & 24 & 3 & 4 \\
\hline ППП № 4К & 12 & 55 & 21 & 6 & 6 \\
\hline ППП № 5 & 10 & 60 & 24 & 3 & 3 \\
\hline ППП № 5К & 18 & 58 & 15 & 6 & 3 \\
\hline ППП № 6 & 16 & 56 & 21 & 4 & 3 \\
\hline ППП № 6К & 20 & 52 & 19 & 6 & 3 \\
\hline
\end{tabular}

Подібний аналіз розподілу деревостанів сосни за категоріями панування та життєвості відзначено на ППП № 5 та ППП № 5К. Так, частка дерев I та II класів на ППП № 5 становить 70 \%, а на ППП № 5К - 78 \%. Аналіз розподілу частки деревостанів за III класом свідчить, що на ППП № 5 їх більше у 1,6 раза, порівняно 3 ППП № 5К. На ППП № 6 та ППП № 6К встановлено, що максимальна кількість деревостанів належить до II класу і перевищує 50 \% від загального обсягу. Частка насаджень I класу на ППП № 6К у 1,2 раза більша, ніж на ППП № 6, проте для III класу виявлено протилежну закономірність. За результатами розподілу дерев за класом Крафта можна зробити висновок, що найбільша їхня частина припадає на I та II клас. Так, на ППП № 4 та № 4К ці класи становлять 69 та $67 \%$ відповідно; ППП № 5 та № $5 \mathrm{~K}$ - 70 та 78 \%; ППП № 6 та № $6 \mathrm{~K}$ - по $72 \%$. Частка дерев III класу має амплітуду коливання від 15 до 24 \% у межах всіх пробних площ. Частка розподілу дерев IV та V класу є невисокою та не перевищує 6 \% у межах кожної пробної площі.

Було проаналізовано розподіл дерев сосни за класом товарності, що характеризує товарну цінність деревного запасу. Дослідження розподілу дерев за класом товарності було здійснено на кожній пробній площі (рис. 3).

Порівнюючи розподіл деревостанів за класами товарності, на ППП № 4 та ППП № 4К було виявлено такі 
закономірності: на ППП № 4К у 1,2 раза більше дерев належать до I класу (ділова деревина), ніж на ППП № 4. Розподіл за II класом (напівділова деревина) майже однаковий і становить 43 та $42 \%$ відповідно. Проте під час аналізу III класу товарності відзначено, що на ППП № 4 у 1,7 раза більше дров'яної деревини, ніж на ППП № 4К (12\%). Проводячи однофакторний дисперсійний аналіз, було встановлено відсутність різниці середніх значень величин класу товарності між ППП № 4 та ППП № 4К: $F_{\text {факт. }}=2,0<F_{(1 ; 199 ; 0,95)}=3,88$.

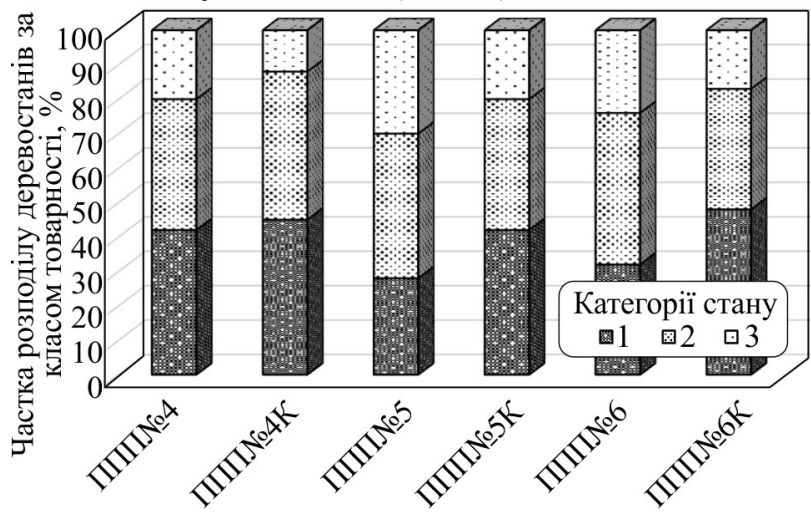

Рис. 3. Розподіл дерев за класами товарності на постійних пробних площах

Подібний аналіз було проведено для ППП № 5 та ППП № 5К, ППП № 6 та ППП № 6К. Результати цього аналізу свідчать, що на контрольних площах частка I класу деревостану становила на ППП № 5 К - $42 \%$ та ППП № 6К - 48\%, тоді як на ППП № 5 та ППП 6 у 1,5 раза менша. Під час аналізу II класу товарності можна відзначити протилежні закономірності, так на ППП № 5 у 1,1 раза більше, ніж на ППП № 5К, а на ППП № 6 у 1,3 раза. Частка розподілу дерев III класу товарності на ППП № 5 та ППП № 6 у 1,5 та 1,4 раза більша, ніж на ППП № 5К та ППП № 6К відповідно. За результатами однофакторного дисперсійного аналізу можна стверджувати, що на 95-\%-ому довірчому рівні існує різниця середніх значень величин класу товарності соснових насаджень: для ППП № 5 та ППП № $5 \mathrm{~K}-F_{\text {факт. }}=$ $4,9>F_{(1 ; 199 ; 0,95)}=3,88$ та ППП № 6 та ППП № 6 К $-F_{\text {факт. }}$ $=4,7>F_{(1 ; 199 ; 0,95)}=3,88$. Аналізуючи розподіл деревостанів за класом товарності, можна припустити, що розподіл дерев за цим показником залежить від якості та своєчасності вживання лісогосподарських заходів.

Висновки. На основі проведених досліджень можна зробити такі висновки:

1. Розподіл деревостанів за категоріями санітарного стану свідчить, що в Народицькому лісництві здорові дерева сосни (І категорія) становили від 29 до 33 \%, ослаблені сосни (II категорія) - 29-33 \%, дуже ослаблені (III категорія) - 13-17\%, всихаючі та всохлі (IV-VI категорії) 22-24 \%. У Малинському лісництві деревостани I категорії становлять 47-53\%, II - 29-37\%, III - 6-12\%, IV-VI - 9-12 \% від загальної кількості дерев.

2. Індекс санітарного стану соснових насаджень у Малинському лісництві знаходиться в межах від 1,89 до 2,13, що відносить насадження до послаблених, а в Народицькому лісництві цей індекс змінюється від 2,45 до 2,57, що свідчить про дуже послаблений стан насаджень.

3. За результатами розподілу дерев за класом Крафта можна зробити висновок, що в обох лісових господарствах найбільша їхня частина припадає на I та II клас. Частка дерев III-V класу є незначною.
4. Отриманні показники розподілу деревостанів за класом товарності деревини свідчать, що в Малинському лісництві частка дерев I категорії значно вища, порівняно 3 Народицьким лісництвом (ППП № $4-38 \%$, ППП № 4К - $45 \%$, ППП № 5 - $28 \%$, ППП № 5 К - $42 \%$, ППП № $6-32 \%$, ППП № 6К - 48 \%). Водночас на радіоактивно забруднених територіях значно зростає частка деревостанів II та III класів.

\section{Перелік використаних джерел}

Buntova, O. H., \& Kuchma, M. D. (2011). Fitopatolohichi obstezhennia ta ekolohichnyi stan lisiv zony vidchuzhennia cherez 25 rokiv pislia avarii na ChAES. Bulleten ekolohichnoho stanu zony vidchuzhennia ta zony bezumovnoho (oboviazkovoho) vidselennia, 1(37), 73-78. [In Ukrainian].

Buzun, V. O., Irkliienko, S. P., \& Turchak, F. M. (2000). Vidpad v sosnovykh kulturakh zony bezumovnoho vidselennia. Problemy ekolohii lisiv i lisokorystuvannia na Polissi Ukrainy, 1(7), 88-95. [In Ukrainian].

Kozubov, G. M., et al. (1990). Radiatcionnoe vozdeistvie na khvoinye lesa v raione avarii na Chernobylskoi AES. Syktyvkar, 136 p. [In Russian].

Krasnov, V. P. (1998). Radioekolohiia lisiv Polissia Ukrainy. Zhytomyr: Volyn, 112 p. [In Ukrainian].

Krasnov, V. P., Buzun, V. O., \& Prystupa, H. K. (1998). Stan i produktyvnist sosnovykh nasadzhen svizhoho suboru na terytorii zony bezumovnoho vidselennia. Problemy ekolohii lisiv i lisokorystuvannia na Polissi Ukrainy, 5, 5-13. [In Ukrainian].

Krasnov, V. P., et al. (1993). Nakoplenie tceziia-137 osnovnymi lesoobrazuiushchimi porodami Polesia Ukrainy. Forestry, 6, 36-37. [In Russian].

Krivolutckii, D. A., et al. (1988). Deistvie ioniziruiushchei radiatcii na biotcenoz. Moscow: Science. [In Russian].

Kuchma, M. D., Arkhipov, M. P., Bidna, S. M., \& Dzhyhar, O. O. (1997). Radioekolohichna ta lisivnycha sytuatsiia v lisakh zony vidchuzhennia. Nauka. Chornobyl-96. Collection of Reports of Scientific and Practical Conference, (pp. 121-127). [In Ukrainian].

Kuchma, M. D., et al. (1996). Lisovi ekosystemy. Bulleten ekolohichnoho stanu zony vidchuzhennia, 2, 36-53. [In Ukrainian].

Kuchma, M. D., Fedotov, I. S., Arkhipov, M. P., \& Pasternak, P. S. (1996). Ekoloho-lisivnychi naslidky radioaktyvnoho zabrudnennia lisovykh masyviv zony vidchuzhennia ChAES. Bulleten ekolohichnoho stanu zony vidchuzhennia, 2, 12-18. [In Ukrainian].

Maradudin, I. I. (1991). Lesnoe khoziaistvo v usloviiakh radioaktivnogo zagriazneniia. Obzornaia informatciia, 1, 40. Moscow: VNIITclesresurs. [In Russian].

Mozolevskaia, E. G. (1991). Otcenka sostoianiia i ustoichivosti nasazhdenii. Tekhnologiia zashchity lesa, 234-237. [In Russian].

Pasternak, P. S., et al. (1990). Vliianie ioniziruiushchego izlucheniia na sostoianie sosnovykh nasazhdenii. Lesovodstvo i agrolesomelioratciia, 80, 50-53. [In Russian].

Pliuta, P. H., \& Didukh, Ya. P. (1996). Fitoekolohichni doslidzhennia $\mathrm{v}$ zoni vidchuzhennia ChAES. Problemy Chornobylskoi zony vidchuzhennia, 3, 39-48. [In Ukrainian].

Savitckii, E. A. (1992). Sostoianie kultur sosny obyknovennoi (Pinus silvestris L.) v usloviiakh radioaktivnogo zagriazneniia Kievskogo Polesia. Abstract of Candidate Dissertation for Agricultural Sciences. Kyiv: USKhA. [In Russian].

Shcheglova, A. I., \& Tcvetnova, O. B. (2001). Rol lesnykh ekosistem pri radioaktivnom zagriaznenii. Nature, 4, 22-32. [In Russian].

Stepanchik, V. V., Usanova, E. N., \& Savluk, S. V. (1997). Indeks sanitarnogo sostoianiia nasazhdenii, kak pokazatel ikh ustoichivosti $\mathrm{k}$ vozdeistviiu aerotekhnogennogo zagriazneniia. Lesnaia nauka na rubezhe XX1 veka. Scientific works of the Forest Institute of the National Academy of Science of Belarus, 40, 390-394. Gomel: FI of the NAS of Belarus. [In Russian].

Stepin, V. V., \& Biriukov, V. I. (1993). Ustoichivost lesnykh biogeotcenozov i puti ee povysheniia. Moscow: VNIITclesresurs. [In Russian].

Tikhomirov, F. A., Shcheglov, A. I., \& Sidorov, V. P. (1994). Les i lesnoe khoziaistvo v usloviiakh radiatcionnogo zagriazneniia. Forestry, 1, 26-29. [In Russian]. 


\section{ASSESSMENT OF THE SANITARY CONDITION OF THE SCOTCH PINE PLANTATUONS IN FRESH PINE FORESTS OF UKRAINIAN POLISSIA EXCLUSION ZONE}

The paper presents the results of the assessment of the sanitary condition of pine plantations in the fresh pine forests of Ukrainian Polissya in the areas where proper forest management measures are being undertaken - Malynske Forestry SE and where forestry activities were prohibited due to the significant levels of radioactive contamination of the territory - Narodytske Specialized Forestry SE. In pine forests of all age groups, where forestry activities have been terminated, the share of healthy stands is lower than in noncontaminated stands, the main share is presented by stands of II-IV category. The obtained results are confirmed by one-factor dispersion analysis, which shows that there is a significant difference between the distribution of trees according to the condition categories on the tested plots of the SP № 5/5K and SP6/6K: $F_{\text {fact. }}=11.2>F_{(1 ; 199 ; 0,95)}=3,9$ and $F_{\text {fact. }}=12.6>F_{(1 ; 199 ; 0,95)}=$ 3.9 respectively. It was found that there was no significant difference in the SP № 4/4K between the investigated parameters $-F_{\text {fact. }}=$ $3.0<F_{(1 ; 199 ; 0,95)}=3.9$. Regular deterioration of the index of sanitary condition of radioactively contaminated pine stands to 2.4-2.57 against 1.89-2.1 in the controlled tree stands is observed. The distribution of trees according to the degree of domination and vitality (Craft category) shows that the largest share of the tree stands falls on the first and second category. It was found that on the controlled sample plots the percentage of tree stands distribution by the categories of wood merchantability is considerably better (I $42-48 \%$, II $-35-43 \%$, III - 12-20\%) than in radioactively contaminated territories (I - 28-38 \%, II - 42-44 \%, III - 20-30 \%). The distribution of trees according to this indicator depends on the quality and timeliness of forest management activities. We should note that pine stands on the controlled sample plots were more structurally stable.

Keywords: radioactive contamination; forestry activities; sanitary condition index; Craft category; category of wood merchantability. 